\title{
Streptococcus Mutans Infections in Infants and Related Maternal and Child Factors
}

\section{Zaraženost dojenčadi bakterijom Streptococcus mutans $i$ čimbenici povezani s majkom i djetetom}

\author{
${ }^{1}$ Department of Pediatric and Preventive Dentistry, University Dentistry Clinical Center of Kosovo, 10000 Prishtina, Kosovo \\ Zavod za pedodonciju i preventivnu stomatologiju Sveučilišnoga stomatološkoga kliničkoga centra Kosova, 10 ooo Priština, Kosovo \\ 2 Centres Dentaires Véronneau, Quebec, Canada \\ Centres Dentaires Véronneau, Quebec, Kanada
}

\begin{abstract}
Objective: The aim of the study was to investigate the maternal-child S. mutans infection, mutual interaction and potential risk factors altering this interaction. Material and methods: A total of 160 mothers who were paired with their children were recruited. Saliva from mothers and children was collected and $S$. mutans categorized levels were analyzed. A questionnaire was used to collect maternal and child conventional caries risk factors. A proportional odds regression model was used to investigate whether the level of infection of mothers would similarly affect the level of infection of their children, thus adjusting for other risk factors. Results: The average age of mothers was 28.1 years and children had a median age of 5.1 months. Paired mother-child S. mutans cross-classification into non-infected and infected subjects showed no agreement in mutual contamination. Maternal infection of the child was highest when the mother was infected with $10^{33} \mathrm{~S}$. mutans $/ \mathrm{ml}$ of saliva. The results obtained by the regression model showed that none of the potential risk factors influenced the level of infection in the child. Conclusion: Mothers with a high S. mutans level increase the risk of S. mutans acquisition for her five- month- old child but no evidence was found that other maternal/ child factors may influence this.
\end{abstract}

Received: February 11, 2021
Accepted: May 17, 2021

Address for correspondence

Aida Rexhepi

University Dentistry Clinical Center of Kosovo

Department of Pediatric and

Preventive Dentistry

10000 Prishtina, Kosovo

aida.n.rexhepi@gmail.com

MeSH terms: Dental Caries; Infectious Disease Vertical Transmission; Infant Author keywords: Streptococcus Mutans; Caries Risk Factors;

Transmission of Infection

\section{Introduction}

Dental caries is one of the most prevalent dental diseases which requires prevention as a first line approach, $(1,2)$ especially the form of caries known as early childhood caries (ECC) (3). In children younger than 3 years of age, any sign of smooth-surface caries is indicative of severe early childhood caries (S-ECC) (4).

The consequences of this early form of carious lesions include a higher risk of new carious lesions, an increased cost of dental treatment and time, emergency visits, an increased number of days with restricted activity, later caries in the permanent dentition and malocclusion $(2,5)$.

S. mutans is the main causative bacterium of human dental caries and plays an important role in etiology of ECC. Moreover, it is crucial in its initial phase $(6,7)$. The initiation of dental caries is preceded by the colonization of dentition by $S$. mutans, usually in early childhood (8). The early establishment of these bacteria in the mouth of human infants is mainly dependent on the maternal transmission of saliva (9). The higher the level of $S$. mutans in the maternal saliva, the more likely is the colonization of primary dentition by cario-
Uvod

Karijes je jedna od najraširenijih bolesti zuba koja, kao glavni pristup, zahtijeva prevenciju $(1,2)$, osobito oblik poznat kao karijes ranoga djetinjstva (engl. early childhood caries - ECC) (3). Kod djece mlađe od tri godine svaki znak karijesa na glatkim površinama može upozoravati na teški karijes ranog djetinjstva (engl. severe early childhood caries - SECC) (4).

Posljedice toga ranoga oblika karijesa su veći rizik od nastanka novih karijesnih lezija, povećani troškovi stomatološkog liječenja i više utrošenog vremena, hitni pregledi, povećan broj dana $s$ ograničenom aktivnošću, karijes u trajnoj denticiji i malokluzija $(2,5)$.

Streptococcus mutans (S. mutans) glavni je bakterijski uzročnik ljudskoga zubnoga karijesa i važan je u etiologiji ECCa. Štoviše, ključan je u početnoj fazi $(6,7)$. Pojavi zubnoga karijesa prethodi kolonizacija denticije bakterijom $S$. mutans, obično u ranom djetinjstvu (8). Rana pojava tih bakterija u ustima dojenčadi uglavnom ovisi o prijenosu preko sline majke (9). Što je veća razina te bakterije u majčinoj slini, to je veća vjerojatnost kolonizacije primarne denticije kariogenim 
genic bacteria (10). The earlier the colonization, the higher is the incidence of carious lesions (11).

This significant correlation between a high caries experience and high $S$. mutan's counts has been demonstrated in studies $(12,13)$. Moreover, the delay of colonization by $S$. mutans is associated with a lower caries experiences in the future (14). The acquisition of $S$. mutants may occur very early, even before the teeth erupt (15). Key factors involved in the oral colonization of the cariogenic group of bacteria, $S$. mutants in young children, need to be studied further (16). Even though several previous studies have tried to document $S$. mutans mother-child transmission and the related factors, nevertheless, some essential aspects remain elusive (6). Specifically, previous studies (17-21) in this area of maternal S. mutans transmission have shown significant associations using different designs, but this needs further study. Several previous studies looked at qualitative transmission (strains), while our study reports detailed categorical quantitative correlation. The key threshold of $S$. mutans needed to initiate the caries process is $10^{5} / \mathrm{ml}$ of saliva, however, this needs to be studied further to see how it impacts a mother-child transmission, and more evidence is needed on vertical contamination (19). Another additional issue that needs clarifying is the specific factors affecting maternal-infant early $S$. mutans transmission. Previous studies (18-21) have explored some of the maternal and older child factors looking for the potential factors mediating $S$. mutans interaction. To our knowledge, no clinical study has looked into the mother-infant qualitative and quantitative $S$. mutans detailed interaction or explored specific potential factors that may have an impact on this transmission. Therefore, the aim of this study was to develop knowledge on the maternal-infant $S$. mutans transmission and identify new caries risk factors that may contribute to this transmission. This initiative is inspired by the medical strategies in ECC prevention such as controlling $S$. mutans colonization rather than mechanical approaches as suggested by Kohler (20).

We hypothesized that the specific factors determined for the study would have an impact on maternal-infant early $S$. mutans transmission.

\section{Methods}

\section{Study design and participants}

The study design was cross-sectional where maternal/ child measurements for the number of $S$. mutans were performed once. Data collection lasted for a period of 7 months (04-10/2016). A recruitment of 160 voluntary participants was randomly generated from a principal sample of 300 mothers and their young children used for another study that had already been published based on our inclusive criteria (22). The study was carried out in the Main Family Medical Centre (MFMC) of Pristina, the capital of Kosovo. This specific site was considered for data collection since the patients visiting MFMC come from different backgrounds, thus representing a diverse sample for the study.

The inclusion criteria for the study were: if mothers were exposed to the study questionnaire and if the child in the bakterijama (10). Što je ranija kolonizacija, to je veća učestalost karijesnih lezija (11).

Ta značajna povezanost između visoke incidencije karijesa i visoke razine $S$. mutans pokazala se u istraživanjima (12, 13). Štoviše, kasnija kolonizacija povezana je $s$ nižom incidencijom karijesa u budućnosti (14). Kolonizacija tom bakterijom može se dogoditi vrlo rano, čak i prije nicanja zuba (15). Ključne čimbenike koji su bitni za oralnu kolonizaciju kariogenih bakterija $S$. mutans kod male djece potrebno je dodatno proučiti (16). Iako su autori nekoliko istraživanja pokušali dokumentirati prijenos $S$. mutans s majke na dijete i povezane čimbenike, ipak neki važni aspekti ostaju nepoznanica (6). Konkretno, u dosadašnjim istraživanjima (17 21) o prijenosu $S$. mutans s majke na dijete istaknuta je značajna povezanost $s$ primijenjenim dizajnom istraživanja, ali to zahtijeva daljnje proučavanje. U nekoliko istraživanja autori su se bavili kvalitativnim prijenosom (sojevi), a u našemu izvješćujemo o detaljnoj kategorijalnoj kvantitativnoj korelaciji. Prag $S$. mutans potreban za inicijaciju procesa pojave karijesa jest $105 / \mathrm{mL}$ sline, no to je potrebno dodatno proučiti da bi se vidjelo kako utječe na prijenos s majke na dijete, a potrebno je i više dokaza o vertikalnoj kontaminaciji (19). Još jedno dodatno pitanje koje treba razjasniti jest koji specifični čimbenici utječu na rani prijenos $S$. mutans s majke na dojenče. U dosadašnjim istraživanjima $(18-21)$ proučavani su neki čimbenici majki i starije djece te traženi potencijalni čimbenici koji posreduju u interakciji sa $S$. mutans. Prema našim saznanjima ni u jednom kliničkom istraživanju autori nisu proučavali kvalitativnu i kvantitativnu interakciju S. mutans između majke i dojenčeta, ni specifične potencijalne čimbenike koji mogu utjecati na taj prijenos. Zato je cilj ovog istraživanja bio steći spoznaje o prijenosu $S$. mutans $s$ majke na novorođenče i identificirati nove čimbenike rizika za nastanak karijesa koji mogu pridonijeti tom prijenosu. $\mathrm{Ta}$ je inicijativa potaknuta medicinskim strategijama u prevenciji ECC-a, poput kontrole kolonizacije S. mutans, a ne mehaničkim pristupima kako je predložio Kohler (20).

Pretpostavili smo da bi specifični čimbenici određeni u istraživanju utjecali na rani prijenos $S$. mutans s majke na dijete.

\section{Metode}

\section{Ispitanici i metode}

Koncipirano je presječno istraživanje u kojemu je jednokratno mjeren broj S. mutans kod majke i djeteta. Prikupljanje podataka trajalo je sedam mjeseci (od travnja do listopada 2016). Ukupno 160 dobrovoljnih sudionica nasumično je izabrano iz glavnog uzorka od 300 majki i njihove male djece, a ostale su sudjelovale u drugom istraživanju koje je već objavljeno na temelju naših kriterija za uključivanje (22). Istraživanje je provedeno u Glavnom centru za obiteljsku medicinu (MFMC) u glavnome kosovskome gradu Prištini. To je mjesto odabrano za prikupljanje podataka jer pacijenti koji posjećuju MFMC dolaze iz različitih sredina, pa čine raznolik uzorak za istraživanje.

Kriteriji za uključivanje u studiju bili su: majke su trebale ispuniti upitnik i dijete je trebalo biti mlađe od 12 mjese- 
study is under 12 months of age at the moment of saliva collection. The exclusion maternal criteria were receiving chemotherapy or radiotherapy, having a cognitive or physical handicap or having a child being over 12 months of age. Prior to the recruitment of participants, the study was approved by Pristina University Ethics Committee (Ethic CommitteeMedical Faculty, University of Pristina, Ref. Nr. 1851) and all mothers who participated it the study gave their consent.

\section{Study Variables}

The principal dependent variable was the child's levels of S. mutans infection expressed by the categorical and recommended method associated with the commercial test Dentocult SM strip mutans count and as described by Jensen and Bratthall (23).

Bacterial counts were recorded as Colony Forming Units per milliliter $(\mathrm{CFU} / \mathrm{ml})$ of saliva. The numbers of bacterial colonies were graded as Class 0, 1, 2 and 3 according to the manufacturers' scoring-card. Class 0: none detected; Class 1: $<10^{2} \mathrm{CFU} / \mathrm{ml}$; Class 2: $<10^{3-4} \mathrm{CFU} / \mathrm{ml}$; Class 3: $>10^{25} \mathrm{CFU} /$ $\mathrm{ml}$.

The principal independent variable was the mother's levels of $S$. mutans expressed by the same test and method as their child. Other independent variables of interest were family socio -demographic, economic and behavioral data that were obtained through administrated questionnaires provided for mothers of the children that were being investigated. The information obtained from the mother was set at her level of education, on her last dental visit, knowledge on when to start tooth brushing of the child, on her frequency of daily brushing, on her own oral health perception and on her past caries experiences. The information obtained on the child was the presence or not of his/her teeth and the number of times he/she has been ill. The examiner was asked to observe the mother and to check the upper anterior teeth to see if there was any dental plaque or clinical changes relating to past or present caries experiences.

\section{Collection of the variables}

Saliva collection was carried out using the method by Dentocult SM stripmutans test (23) using a plastic strip. All samples of saliva were collected by a dentist or a $\mathrm{PhD}$ candidate. Maternal questionnaires were also administrated by the same examiner.

\section{Data analysis}

For each categorical and continuous variable of interest, the counts and percentages were reported, as well as the median and inter-quartile range (IQR $=75^{\text {th }}$ percentile $-25^{\text {th }}$ percentile). To investigate the association between maternal $S$. mutans infection and their child a $S$. mutans acquisition the McNemar's test was used (24), and the kappa coefficient of agreement between the categories was calculated. Also the proportions of infected children within the cohort of infected mothers were compared. To investigate the marginal effect of the level of $S$. mutans infection in the mother on the outcome of the level of $S$. mutans infection in the child a regression model was used to take into account the ordinal nature of the coding for this outcome. The regression model was ad- ci u trenutku prikupljanja sline. Kriteriji za isključivanje bili su odlazak majski na kemoterapiju ili radioterapiju, kognitivni ili tjelesni nedostatak ili dijete starije od 12 mjeseci. Prije uključivanja sudionica istraživanje je odobrilo Etičko povjerenstvo Sveučilišta u Prišstini (Etičko povjerenstvo Medicinskog fakulteta Sveučilišta u Prištini, broj 1851), a sve majke koje su sudjelovale potpisale su pristanak.

\section{Ispitivane varijable}

Glavna ovisna varijabla bila je djetetova razina infekcije bakterijom $S$. mutans izražena kategoričkom i preporučenom metodom na temelju komercijalnoga testa broja bakterija u obliku trakica Dentocult SM, kako su opisali Jensen i Bratthall (23).

Broj bakterija zabilježen je kao jedinica za formiranje kolonije po mililitru sline (Colony Forming Units, $\mathrm{CFU} / \mathrm{mL}$ ). Broj bakterijskih kolonija klasificiran je u razrede 0, 1, 2 i 3 prema indeksu proizvođača: razred 0 - nisu otkrivene; razred $1-<10^{2} \mathrm{CFU} / \mathrm{mL}$; razred $2:-<10^{3-4} \mathrm{CFU} / \mathrm{mL}$ i razred 3 $\rightarrow 10 \geq 5 \mathrm{CFU} / \mathrm{mL}$.

Glavna nezavisna varijabla bila je majčina razina $S$. mutans izražena istim testom i metodom kao kod djeteta. Druge nezavisne varijable koje su bile zanimljive bili su socijalno-demografski, ekonomski i bihevioralni podatci o obitelji koji su dobiveni iz administrativnih upitnika za majke djece uključene $u$ istraživanje. Tražene su informacije o razini obrazovanja majke, njezin posljednji posjet stomatologu, znanje o tomu kada treba početi prati zube djeteta, učestalost svakodnevnoga pranja zuba, vlastita percepcija oralnoga zdravlja i iskustva s karijesom. Podatci dobiveni o djetetu bili su ima li ili nema zube i koliko je puta bilo bolesno. Ispitivač je pregledao majku i provjerio gornje prednje zube kako bi ustanovio ima li na zubima naslage ili jesu li se pojavile kliničke promjene povezane s prošlim ili sadašnjim karijesom.

\section{Prikupljanje varijabli}

Prikupljanje sline provedeno je testom Dentocult SM stripmutans (23) s pomoću plastične trake. Sve uzorke prikupio je stomatolog ili doktorand. Istom ispitivaču majke su predale $\mathrm{i}$ ispunjene upitnike.

\section{Analiza podataka}

Za svaku odabranu kategorijalnu i kontinuiranu varijablu prikazani su brojevi i postotci te srednji i međukvartilni raspon (IQR $=75$. percentil-25. percentil). Za istraživanje povezanosti majčine infekcije bakterijom $S$. mutans i dobivenog broja $S$. mutans kod djeteta korišten je McNemarov test (24), te je izračunat kappa koeficijent slaganja između kategorija. Također je uspoređen udio zaražene djece u skupini inficiranih majki. Za istraživanje marginalnog učinka razine infekcije $S$. mutans kod majke na ishod razine djetetove zaraze, korišten je regresijski model kako bi se uzela u obzir ordinalna priroda kodiranja za taj rezultat. Regresijski model prilagođen je da bi se uzeli u obzir drugi odabrani čimbenici rizika (tablica 1.), proporcionalne mogućnosti ili kumulativni 
justed to take into account other risk factors of interest (Table 1), the proportional odds or cumulative logits. The results were reported as odds ratios (OR) with a $95 \%$ confidence interval (CI).

All statistical tests of the hypothesis were two-sided and performed at a significance level of 5\%. All statistical analyses were done using the SAS software, version 9.3 (SAS Institute Inc., Cary, NC, USA) (25).

\section{Results}

The study included 160 mother/child pairs. The median age of the mothers was 28.0 years (IQR 26-31) and the median of the children was 5 months (IQR 4-12, in that last case, due to a skewed distribution, we used median instead mean). The results showed that more than half of the mothers $(54.4 \%)$ had graduated from university and almost half of them (48\%) had a low family income. Almost all mothers were infected by $S$. mutans $(150 / 160,93.8 \%)$. The rate of infection for the infants was $70.6 \%(113 / 160)$. logiti. Rezultati su prikazani kao omjeri vjerojatnosti (OR) s 95-postotnim intervalom pouzdanosti (CI).

Svi statistički testovi hipoteza bili su dvostrani i izvedeni su na razini značajnosti od $5 \%$. Sve statističke analize obavljene su u softveru SAS, verzija 9.3 (SAS Institute Inc., Cary, NC, SAD) (25).

\section{Rezultati}

Istraživanje je obuhvatilo 160 parova majki i djece. Srednja dob majki bila je 28,0 godina (IQR 26 - 31), a medijan djece pet mjeseci (IQR $4-12$, u tom slučaju, zbog iskrivljene distribucije, umjesto prosječnih vrijednosti korišten je medijan). Rezultati su pokazali da je više od polovine majki $(54,4$ $\%$ ) završilo fakultet i gotovo isto toliko (48 \%) imalo je niske obiteljske prihode. Gotovo sve majke bile su inficirane bakterijom S. mutans (150/160, 93,8 \%). Stopa infekcije dojenčadi bila je 70,6 \% (113/160).

\begin{tabular}{|c|c|c|}
\hline \multicolumn{2}{|c|}{ Categories $\bullet$ Kategorija } & \multirow{2}{*}{$\begin{array}{l}\text { n (\%) } \\
28.14\end{array}$} \\
\hline Mother mean age $\bullet$ Prosječna dob majke & Years • Godina $(26-31)$ & \\
\hline Child median age $\bullet$ Prosječna dob djeteta & Months $\bullet$ Mjeseci (4-12) & 5.01 \\
\hline \multirow{2}{*}{ Mother level of education $\bullet$ Majčina razina edukacije } & Graduated from high school or less? $\bullet$ Srednja škola ili niže & $73(45.6 \%)$ \\
\hline & Graduated from College or University? • Završen fakultet & $87(54.4 \%)$ \\
\hline \multirow{3}{*}{ Family income (monthly) $\bullet$ Obiteljski prihodi (na mjesec) } & Less than $500 € \bullet$ Manje od $500 €$ & $77(48.1 \%)$ \\
\hline & $600-1,000 €$ & $66(41.3 \%)$ \\
\hline & $1,000-3,000 €$ & $17(10.7 \%)$ \\
\hline \multirow{2}{*}{ Mother infection by $S$. mutans $\bullet$ Infekcija majke bakt. $S$. mutans } & Yes $\bullet \mathrm{Da}$ & $150(93.8 \%)$ \\
\hline & $\mathrm{No} \bullet \mathrm{Ne}$ & $10(6.2 \%)$ \\
\hline \multirow{2}{*}{ Child infection by $S$. mutans $\bullet$ Infekcija djeteta bakt. S. mutans } & Yes $\bullet \mathrm{Da}$ & $113(70.6 \%)$ \\
\hline & $\mathrm{No} \cdot \mathrm{Ne}$ & $47(29.4 \%)$ \\
\hline
\end{tabular}

A cross-classification was performed for the mother-child dyad for the presence of infection (Table 2). It was found that children of infected mothers would not necessarily be infected and that children of non-infected mothers would also be non-infected, i.e. the off-diagonal counts were not very small (McNemar's test $p<0.0001)$. This result was validated by a very small kappa coefficient 0.04 . However, in the group of infected mothers, the proportion of infected children was $71.3 \%(107 / 150)$, with a $95 \%$ CI $(64.1 \%, 78.6 \%)$ (Test for proportion, $\mathrm{Z}=5.23, p<0.0001)$. The proportions were not significantly different in the group of non-infected mothers.
Učinjena je ukrižena klasifikacija za dijadu majka/dijete za prisutnost infekcije (tablica 2.). Utvrđeno je da djeca zaraženih majki ne moraju nužno biti inficirana te da će i djeca nezaraženih majki biti nezaražena, tj. broj izvan dijagonale nije bio veoma malen (McNemarov test $\mathrm{p}<0,0001)$. Taj je rezultat potvrđen vrlo malim kappa koeficijentom od 0,04 . No u skupini inficiranih majki udio zaražene djece bio je $71,3 \%$ (107/150), s $95 \%$ CI-a $(64,1 \%, 78,6 \%)$ (test za udio, $Z=5,23, p<0,0001)$. U skupini nezaraženih majki omjeri se nisu značajno razlikovali.

Table 2 Mother-child dyads according to infection status

Tablica 2. Dijada majka - dijete prema statusu infekcije

\begin{tabular}{|c|c|c|c|}
\hline \multicolumn{2}{|c|}{ Child $\bullet$ Dijete } & Totals $\bullet$ Ukupno \\
\hline Mother $\bullet$ Majka & No $\bullet$ Ne & Yes $\bullet$ Da & 10 \\
\hline No $\bullet$ Ne & 4 & 6 & 150 \\
\hline Yes $\bullet$ Da & 43 & 107 & 160 \\
\hline Totals $\bullet$ Ukupno & 47 & 123 & $<0.0001^{*}$ \\
\hline
\end{tabular}


When the level of infection of the mother/child dyad is considered, a cross-classification shows the same level of infection (class $1-10^{2}$ ) present in 22 of the mother/child dyads. This shows that there is a very low correlation between the level of infection categories on the mother/child dyad $($ McNemar's test, $p<0.0001$; weighted kappa $=0.05)$.
Kada se uzme u obzir razina infekcije dijade majka/dijete, ukrižena klasifikacija pokazuje istu razinu infekcije (razred $\left.1-10^{2}\right)$ u 22 dijade majka/dijete. To pokazuje da je vrlo niska korelacija između razine kategorija infekcije u dijadi majka/dijete (McNemarov test, $\mathrm{p}<0,0001$; ponderirana kappa $=0,05)$.

Table 3 S. mutans child infection associated to mothers one

Tablica 3. Infekcija djeteta bakterijom S. mutans povezana s majčinom

\begin{tabular}{|c|c|c|c|c|c|}
\hline \multirow{2}{*}{$\begin{array}{c}\text { Mother } S . \text { mutans levels } \\
\text { Majčina razina bakt. } S . \text { mutans }\end{array}$} & \multicolumn{4}{|c|}{$\begin{array}{l}\text { Child } S \text {. mutans levels in CFU } / \mathrm{ml} \text { of saliva } \\
\text { Djetetova razina bakt. S. mutans u CFU } / \mathrm{mL} \text { sline }\end{array}$} & \multirow[t]{2}{*}{ Total • Ukupno } \\
\hline & 0 & $10^{2}$ & $10^{3-4}$ & $10^{25}$ & \\
\hline 0 & 4 & 1 & 4 & 1 & $10(6.2 \%)$ \\
\hline $10^{2}$ & 14 & 22 & 8 & 4 & $48(30.0 \%)$ \\
\hline $10^{3-4}$ & 18 & 20 & 12 & 4 & $54(33.7 \%)$ \\
\hline $10^{25}$ & 11 & 23 & 5 & 9 & $48(30.0 \%)$ \\
\hline Total • Ukupno & $47(29.4 \%)$ & $66(41.2)$ & $29(18.1 \%)$ & $18(12.1 \%)$ & 160 \\
\hline
\end{tabular}

We then performed an additional analysis and obtained the results from a proportional odds regression model, which was later used to investigate whether the level of infection of the mother would similarly affect the level of infection of their children, adjusting for other factors. The results showed that none of the risk factors influenced the child's level of infection.

\section{Discussion}

The results of this study have shown that $70.6 \%$ of the young children were infected by $S$. mutans. Similar results were obtained in a study conducted by Damle et al. (2016) (25), $77.3 \%$ of young children were found to have $S$. mutans, up to $30 \%$ of the 3-month-old children were infected, whereas children who were 6 months old had an infection rate which increased to $60 \%$. On the contrary, other studies have shown different results for $S$. mutans infection; in children 6-18 months old the infection rate was found to be $27 \%, 30 \%$ and $53 \%$ (26). S. mutans can be found at early ages: Milgrom et al. (27) found the prevalence to be $53 \%$ in 6 to 12 -month-old children, although Karn et al. found the prevalence in 15 -month-olds was $60 \%$ (28).

The high level of $S$. mutans infection was also found to be present in mothers who were included in the study. The result of $93.8 \%$ of infected mothers with bacteria shows a very high rate of infection. Li et al. (2000) also reported a high level of infection of $87.5 \%$ among mothers (29), whereas in a pilot study $(\mathrm{n}=10)$ S. mutans was found in all mothers (23).

One of the study objectives was to report on $S$. mutans infection in infants taking into consideration the level of maternal infection. The results illustrate a true dose-response between the high maternal $S$. mutans infection rate, $10^{3}-10^{5}$ organisms per milliliter of saliva, and the subsequent child $S$. mutans colonization rate $(63.7 \%)$, whereas in low maternal $S$. mutans infection, $0-10^{2}$ organisms per milliliter of saliva, only $36.2 \%$ of children had a $S$. mutans infection. From the literature review, no studies were found which investigated the mutual S. mutans levels of infection in mother and child at such a young age. A previous comparable study by Berkowitz et al. (1981) in children who were 10-16 months old found
Zatim smo obavili dodatnu analizu i dobili rezultate iz modela proporcionalne regresije izgleda koji je poslije iskorišten za istraživanje hoće li razina infekcije majke na sličan način utjecati na razinu infekcije njihove djece, prilagođavajući se drugim čimbenicima. Rezultati su pokazali da ni jedan od čimbenika rizika nije utjecao na razinu infekcije djeteta.

\section{Rasprava}

Rezultati ovog istraživanja pokazali su da je 70,6 \% male djece inficirano bakterijom $S$. mutans. Slični rezultati dobiveni su u istraživanju Damlea i suradnika (2016.) (25) - kod $77,3 \%$ male djece ustanovili su da imaju $S$. mutans, zaraženo je bilo i do $30 \%$ tromjesečne novorođenčadi, a kod djece u dobi od 6 mjeseci stopa infekcije porasla je na $60 \%$. Suprotno tomu, u drugim istraživanjima dobiveni su različiti rezultati za infekciju bakterijom S. mutans - kod djece u dobi od 6 do 18 mjeseci ustanovljena je stopa zaraze od $27 \%, 30 \%$ i $53 \%$ (26). S. mutans može se pronaći u ranoj dobi: Milgrom i suradnici (27) otkrili su da je kod djece od 6 do 12 mjeseci prevalencija $53 \%$, iako su Karn i suradnici istaknuli da je prevalencija 15 -mjesečne djece $60 \%$ (28).

Istaknuto je da je visoka razina infekcije bakterijom $S$. mutans pronađena i kod majki koje su bile uključene u istraživanje. Rezultat od 93,8 \% majki zaraženih bakterijom pokazuje vrlo visoku stopu infekcije. Li i suradnici (2000.) također su izvijestili o visokoj razini infekcije od 87,5\% među majkama (29), a u pilot-istraživanju $(\mathrm{n}=10)$ pronađen je $S$. mutans kod svih majki (23).

Jedan od ciljeva istraživanja bio je izvijestiti o zaraženosti dojenčadi bakterijom $S$. mutans, uzimajući u obzir razinu majčine infekcije. Rezultati ilustriraju pravi odgovor između visoke stope infekcije bakterijama $S$. mutans $-10^{3}$ do $10^{5} \mathrm{mi}-$ kroorganizama po mililitru sline i stope kolonizacije djeteta tom bakterijom $(63,7 \%)$, a pri nižoj razini te bakterije od 0 do $10^{2}$ mikroorganizma po mililitru sline samo je $36,2 \%$ djece imalo infekciju. $U$ literaturi nisu pronađena istraživanja koja su se bavila uzajamnom razinom infekcije bakterijom $S$. mutans kod majke i djeteta u tako mladoj dobi. U usporednom istraživanju su Berkowitz i suradnici (1981.) otkrili kod 
that the frequency of infant infection was approximately nine times greater when maternal salivary levels exceeded $10^{5}$ organisms per $\mathrm{ml}(30)$.

When only the qualitative presence or absence of mother-child infection was taken into consideration, it was found that in the group of infected mothers the proportion of infected children was $71.3 \%(107 / 150)$. This showed that not all infants of infected mothers would also be infected and also not all infants of non-infected mothers would also be non-infected. When the intensity quantitative level of mutual S. mutans infection is considered, from reported associated frequencies (Table 2) or categories (Table 3), a significant linear correlation construction was not found between both distributions. Previous studies on older children (31, 32) confirmed a quantitative correlation. In general, $S$. mutans infections in children either by primary sources (33) or time expression $(14,33)$ have been reported as very varied. This may explain why no symmetric $S$. mutans distribution was found. Also, other studies have depicted that $S$. mutans is readily acquired from nonmaternal sources in certain populations (34).

Another objective of the study was to assess $S$. mutans infection between the mother and her infant in detail and to evaluate the potential risk factors that may impact on this. It is documented that $S$. mutans from either the mother or caregiver is the main source for early child acquisition (32). The most potential ECC and S. mutans transmission risk factors are partially documented from previous studies: maternal socio-demographic and economic status, oral hygiene practices (35), maternal clinical observations and caries experiences $(16,35)$ child dietary behaviors $(18,20,36,37)$ teeth eruptive timing, breast-feeding duration (29) child enamel defect and low birth weights $(36,37)$ and child sex (36). Therefore distinctive or complementized factors of previous studies based on our review were selected considering notably the age of participants. The factors studied were from maternal demographic, behavior, knowledge and clinical observation collections and child illness episodes. The starting point was first exposure to tooth brushing and tooth presence.

The limitation of our study was a relatively small sample size. The high costs of laboratory analysis and tests were unaffordable; hence we could not include a greater number of participants in the study.

\section{Conclusion}

None of the factors analyzed influenced the impact of maternal infection on their child's S. mutans outcome. Regarding the evaluation of potential factors, a proportional regressive model was used to document whether the maternal $S$. mutans levels of infection would similarly change their child's degree of infection, thus adjusting for other risk factors that were collected.

\section{Funding}

This study was not funded from any grant. All expenses were covered by the authors, but this did not have a role in the design of the study. djece u dobi od 10 do 16 mjeseci da je učestalost infekcije dojenčadi približno devet puta veća ako je razina mikroorganizama u slini majke bila veća od $10^{5}$ po $\mathrm{mL}$ (30).

Kada se uzme u obzir samo kvalitativna prisutnost ili odsutnost infekcije majke i djeteta, ustanovljeno je da je u skupini zaraženih majki udio zaražene djece 71,3 \% (107/150). To je pokazalo da neće biti inficirana sva dojenčad zaraženih majki, a ni sva dojenčad nezaraženih majki neće ostati nezaražena. Kad se uzme u obzir kvantitativna razina intenziteta uzajamne infekcije bakterijom $S$. mutans iz prijavljenih povezanih frekvencija (tablica 2.) ili kategorija (tablica 3.), nije pronađena značajna linearna korelacijska konstrukcija između obiju distribucija. Prethodna istraživanja o starijoj djeci $(31,32)$ potvrdila su kvantitativnu povezanost. Općenito, zabilježene su vrlo različite infekcije bakterijom $S$. mutans kod djece, bilo iz primarnih izvora (33), bilo $s$ vremenskom ekspresijom $(14,33)$. To može objasniti zašto nije pronađena simetrična distribucija $S$. mutans. U drugim je istraživanjima također istaknuto da se $S$. mutans u određenim populacijama lako može prenijeti iz nematerinskih izvora (34).

Drugi cilj istraživanja bio je detaljno procijeniti infekciju bakterijom $S$. mutans između majke i djeteta i procijeniti potencijalne čimbenike rizika koji mogu utjecati na to. Dokumentirano je da je $S$. mutans od majke ili njegovatelja glavni izvor infekcije djeteta (32). Najvjerojatniji čimbenici rizika za prijenos ECC-a i $S$. mutans djelomično su dokumentirani u dosadašnjim istraživanjima - socijalno-demografski i ekonomski status majke, navike u održavanju oralne higijene (35), klinička opažanja majke i iskustva s karijesom $(16,35)$ prehrambeno ponašanje djece $(18,20,36,37)$ vrijeme nicanja zuba, trajanje dojenja (29), defekti na djetetovoj caklini, mala porođajna težina $(36,37)$ i spol djeteta $(36)$. Zato su na temelju našega pregleda odabrani distinktivni ili nadopunjeni čimbenici prethodnih istraživanja, posebno uzimajući u obzir dob sudionika. Proučavani čimbenici bili su iz zbirki demografskih podataka o majci, ponašanju, znanju i kliničkim opažanjima te epizode bolesti djeteta. Početna točka bila je prva izloženost četkanju zuba i prisutnost zuba.

Ograničenje našeg istraživanja bila je razmjerno mala veličina uzorka. Visoke troškove laboratorijskih analiza i ispitivanja nismo mogli podmiriti pa zato $\mathrm{u}$ istraživanje nismo mogli uključiti više sudionika.

\section{Zaključak}

$\mathrm{Ni}$ jedan od analiziranih čimbenika nije utjecao na prijenos $S$. mutans s inficirane majke na dijete. Kad je riječ o procjeni potencijalnih čimbenika, upotrijebljen je proporcionalni regresijski model za dokumentiranje hoće li razina infekcije bakterijom $S$. mutans kod majke na sličan način promijeniti razinu zaraze njezina djeteta, prilagođavajući se tako ostalim prikupljenim čimbenicima rizika.

\section{Financiranje}

Za ovo istraživanje nije dobivena nikakva potpora. Autori su sami podmirili sve troškove, no to nije utjecalo na tijek i rezultate istraživanja. 


\section{Conflict of Interests}

The authors declare that they have no competing interests related to this paper.

Author's contribution: B. L. Xh. - led the project and controlled the implementation process, collected the data. Contributed to the text, was involved in drafting and revising the manuscript. J.V. - had a substantial contribution to statistical processing and data analyzing. A. R. was writing, critically reviewed and edited, and dealt with correspondence. T. K. - data collection, supervision. Sh. B. - contributed to data acquisition, analysis D. A. - contributed to the collection of literature.

\section{Sukob interesa}

Autori nisu bili u sukobu interesa.

Doprinos autora: B. L. X. - vodio projekt, kontrolirao proces provedbe i prikupljao podatke; sudjelovao u pisanju i reviziji rukopisa; J. V. velik doprinos statističkoj obradi i analizi podataka; A. R. - pisao i kritički pregledavao i uređivao tekst te se bavio korespondencijom; T. K. - prikupljanje podataka i nadzor; S. B. - pridonio prikupljanju podataka i analizi; D. A. - pridonio prikupljanju literature.
Sažetak

Svrha: Cilj je bio istražiti infekciju kod majke i djeteta bakterijom S. mutans, međusobnu interakciju i moguće čimbenike rizika koji mijenjaju tu interakciju. Materijali i metode: U istraživanju je ukupno sudjelovalo 160 majki sa svojom djecom. Prikupljena je njihova slina te su analizirane kategorizirane razine S. mutans. Upotrijebljen je upitnik za prikupljanje čimbenika rizika za nastanak karijesa kod majke i djeteta. Model proporcionalne regresije vjerojatnosti korišten je za istraživanje hoće li razina infekcije kod majki na sličan način utjecati na razinu zaraze njihove djece, čime se prilagođavaju drugi čimbenici rizika. Rezultati: Prosječna dob majki bila je 28,1 godina, a djece 5,1 mjesec. Uparena klasifikacija majke i djeteta u nezaražene i zaražene ispitanike bakterijom S. mutans nije pokazala slaganje u međusobnoj kontaminaciji. Majčinska infekcija djeteta bila je najveća kada je majka bila zaražena s $10^{>3} \mathrm{~S}$. mutans $/ \mathrm{mL}$ sline. Rezultati dobiveni regresijskim modelom pokazali su da ni jedan od potencijalnih čimbenika rizika nije utjecao na razinu infekcije kod djeteta. Zaključak: Majke s visokom razinom $S$. mutans povećavaju rizik od prijenosa te bakterije na svoju petomjesečnu djecu, ali nisu pronađeni dokazi da na to mogu utjecati drugi čimbenici povezani s majkom/djetetom.
Zaprimljen: 11. veljače 2021. Prihvaćen: 17. svibnja 2021.

Adresa za dopisivanje

Aida Rexhepi

Sveučilišna klinika za stomatologiju, Kosovo

Zavod za dječju i preventivnu

stomatologiju

10000 Prishtina, Kosovo

e-adresa: aida.n.rexhepi@gmail.com

MeSH pojmovi: zubni karijes;

vertikalni prijenos zarazne bolesti; novorođenče

Ključne riječi: Streptococcus mutans, čimbenici rizika za nastanak karijesa, prijenos infekcije

\section{References}

1. Chandak SBA, Bhardwaj A, Pimpale J, Chandwani M. Comparative evaluation of the efficacy of fluoride varnish and casein phosphopeptide-Amorphous calcium phosphate in reducing Streptococcus mutans counts in dental plaque of children: An in vivo study. J Int Soc Prev Community Dent. Sep-Oct 2016;6(5):423-429.

2. Ximena ACB, Andrés SM, Sandra GO. Differences in Caries Status and Risk Factors among Privileged and Unprivileged Children in Colombia. Acta Stomatol Croat. 2018 Dec;52(4):330-339.

3. Schroth RJ, Star L. Prevalence and risk factors of caregiver reported severe early childhood caries in Manitoba First Nations children: results from the RHS Phase 2 (2008-2010). Int J Circumpolar Health. 2013;72:1-10.

4. American Academy of Pediatric Dentistry. Policy on early childhood caries (ECC): Classifications, consequences, and preventive strategies. The Reference Manual of Pediatric Dentistry. Chicago: American Academy of Pediatric Dentistry, 2020:79-81.

5. Corrêa-Faria P, Freire CM, de Abreu G, Bönecker M, Costa LR. Impact of untreated dental caries severity on the quality of life of preschool children and their families: a cross- sectional study. Qual Life Res. 2018 Dec;27(12):3191-3198.

6. Priya S, Revathy S. Streptococcus Mutans Strains in Mother-Child Pairs of Children with Early Childhood Caries. J Clin Pediatr Dent. 2019;43(4):252-256.

7. Agnello M, Cen L, Mittermuller B, Huang A, Chaichanasakul Tran N, Shi WHX, Schroth RJ. Microbiome Associated with Severe Caries in Canadian First Nations Children. J Dent Res. 2017 Nov;96(12):1378-1385.

8. Li Y, TA. Effect of Antimicrobial Interventions on the Oral Microbiota Associated with Early Childhood Caries. Pediatr Dent. MayJun 2015;37(3):226-44.

9. Finlayson TL, Ramos-Gomez FJ. Prenatal Maternal Factors, Intergenerational Transmission of Disease, and Child Oral Health Outcomes. Dent Clin North Am. 2017 Jul;61(3):483-518.

10. Priyadarshini HR, Fernandes B. Association between maternal child levels of salivary Mutans Streptococci and early childhood caries. Dent Res J (Isfahan). 2013 Nov;10(6):728-31.

11. Laitala $M$, Isokangas $P$, Söderling $E$, Pienihäkkinen K. A cohort study on the association of early mutans streptococci colonisation and dental decay. Caries Res. 2012;46(3):228-33.
12. Ghazal TS, Childers NK, Carter KD, Caplan DJ, Warren JJ, Cavanaugh JE, Kolker J. Mutans Streptococci and Dental Caries: A New Statistical Modeling Approach. Caries Res. 2018;52(3):246-252.

13. Edelstein BL, Smaldone A. Very High Salivary Streptococcus Mu tans Predicts Caries Progression in Young Children. Pediatr Dent. 2016;38(4):325-30.

14. Kishi M, Kishi K, Ohara-Nemoto Y. Relationship of quantitative salivary levels of Streptococcus mutans and S. sobrinus in mothers to caries status and colonization of mutans streptococci in plaque in their 2.5-year-old children. Community Dent Oral Epidemiol. 2009 Jun;37(3):241-9.

15. Plonka KA, Barnett AG, Walsh LJ, Holcombe TH, Seow WK. Mutans streptococci and lactobacilli colonization in predentate children from the neonatal period to seven months of age. Caries Res. 2012;46(3):213-20.

16. Law V, Townsend G. Factors influencing oral colonization of mutans streptococci in young children. Aust Dent J. 2007 Jun;52(2):93-100; quiz 159.

17. Köhler B. Intrafamilial levels of Streptococcus mutans and some aspects of the bacterial transmission. Scand J Dent Res. 1978 lan;86(1):35-42.

18. Brown JP, Junner C, Liew V. A study of Streptococcus mutans levels in both infants with bottle caries and their mothers. Aust Dent J. 1985 Apr;30(2):96-8.

19. Aaltonen AS, Tenovuo J. Association between mother-infant salivary contacts and caries resistance in children: a cohort study. Pediatr Dent. Mar-Apr 1994;16(2):110-6.

20. Thorild I, Lindau-Jonson B, Twetman S. Prevalence of salivary streptococcus mutans in mothers and in their preschool children. Int J Paediatr Dent. 2002 Jan;12(1):2-7.

21. Cheon K, Wiener HW, Whiddon J, Momeni SS, Ruby JD, Cutter GR, Childers NK. Characteristics of Streptococcus mutans genotypes and dental caries in children. Eur J Oral Sci. 2013 Jun;121(3 Pt 1):148-55.

22. Lafiti-Xhemaji B, Veronnéau J, Begzati A, Bytyci A, Kutlovci T, Rexhepi A. Association between salivary level of intection with Streptococcus mutans/Lactobacilli and caries-risk factors in mothers. Eur J Paediatr Dent. 2016 Mar;17(1):70-4.

23. Jensen B. A new method for the estimation of mutans streptococ ci in human saliva. J Dent Res. 1989 Mar;68(3):468-71. 
24. Stokes M, Koch G. Categorical Data Analysis Using the SAS System, ed. r.e. Cary. 2012, NC: SAS Institute Inc.

25. Damle SG, Garg S, Dhindsa A, Beniwal V, Loomba A, Chatterjee S. Transmission of mutans streptococci in mother-child pairs. Indian I Med Res. 2016 Aug;144(2):264-270.

26. Douglass JM, Tinanoff N. Association of Mutans Streptococci Between Caregivers and Their Children. Pediatr Dent. Sep-Oct 2008;30(5):375-87.

27. Milgrom P, Weinsten $P$, Tanner ACR, Manibusan L, Bruss J. Dental caries and its relationship to bacterial infection, hypoplasia, diet, and oral hygiene in 6-to 36-month-old children. Community Dent Oral Epidemiol. 2000 Aug;28(4):295-306.

28. Karn TA, O'Sullivan DM. Colonization of Mutans Streptoccocci in 8-to 15-month-old Children. J Public Health Dent. Summer 1998;58(3):248-9.

29. Li Y, Wang W, Caufield PW. The Fidelity of Mutans Streptococci Transmission and Caries Status Correlate with Breast-Feeding Experience among Chinese Families. Caries Res. Mar-Apr 2000;34(2):123-32.

30. Berkowitz RJ, Turner J, Green P. Maternal salivary levels of Strep Mutans and primary oral infection of infants. Arch Oral Biol. 1981;26(2):147-9.

31. Pannu P, Tewari A, Gauba K, Sujlana A, Gambhir RS. Correlation between mutans streptococci counts of parents and their children residing in Chandigarh, India. J Clin Exp Dent. 2014 Jul 1;6(3):e250-4.

32. Lapirattanakul J, Nomura R, Hamada S, Nakagawa I, Ooshima T. Demonstration of mother-to-child transmission of Streptococuss mutans using multilocus sequence typing. Caries Res. 2008;42(6):466-74.

33. Avasare T, Qian F, Marshall T, Weber-Gasparoni K, Drake D. Longitudinal Study Assessing Factors Associated with Mutans Streptococci Acquisition in Infants and Toddlers. Oral Health Prev Dent. 2017;15(6):543-548.

34. De Soet JJ, Buijs JF, van Loveren C, de Graaff J, Prahl-Andersen B. Transmission of mutans streptococci between mothers and children with cleft lip and/or palate. Cleft Palate Craniofac J. 1998 Sep;35(5):460-4.

35. Wan AKL, Purdie DM, Bird PS, Walsh LJ, Tudehope DI. Oral colonization of streptococcus mutans in six-month-old predentate infants. J Dent Res. 2001 Dec;80(12):2060-5.

36. Kizilci E, Ozalp N, Ayca DY. Vertical and Horizontal Transmission of Streptococcus Mutans and Effective Factors: An In Vivo Study. J Adv Oral Res. 2020;2(11):172-179.

37. Zhou Y, Zhi QH, Tao Y, Qiu RM, Lin HC. Factors associated with colonization of Streptococcus mutans in 8- to 32-month-old children: a cohort study. Aust Dent J. 2013 Dec;58(4):507-13. 